J. Reprod. Fert. (1966) 11, 485-487

BRIEF COMMUNICATION

\title{
THE EFFECT OF X-IRRADIATION OF RABBIT SPERM- ATOZOA IN VITRO IN DIFFERENT GASES ON EGG DEVELOPMENT AND SPERM DEHYDROGENASES
}

\author{
H. M. DOTT*, K. ISHIDA AND M. G. GHANG \\ Worcester Foundation for Experimental Biology, \\ Shrewosbury, Massachusetts, U.S.A.
}

(Received 4th February 1966)

The insemination of mammalian spermatozoa which have been treated in vitro with X-rays at a dose level of 400 to $800 \mathrm{r}$ results in failure of a large number of eggs to develop beyond the blastocyst stage in rabbits (Amoroso \& Parkes, 1947; Chang, Hunt \& Romanoff, 1957); mice (Edwards, 1957) and cattle (Rowson \& Dott, 1964). Higher doses of X-rays caused development of the eggs to fail at earlier stages (Amoroso \& Parkes, 1947; Chang et al., 1957; Edwards, 1957). Yet the metabolism and motility of irradiated spermatozoa appear to be unaffected even by much higher doses of X-rays, at least in those species which have been examined (cf. Mann, 1964). It seems likely that it is the deoxyribonucleic acid (DNA) in the spermatozoa which is affected by $\mathrm{X}$-irradiation rather than their metabolism, motility or fertilizing capacity.

$\mathrm{X}$-rays can, presumably, act on DNA either directly by virtue of their ionizing activity on DNA molecules, or indirectly by producing free radicles. Two of the methods which have been used to protect biological material from the indirect action of ionizing radiation are: (i) performing the irradiation experiment at a low temperature; and (ii) irradiating under anaerobic conditions. The first of these methods was used by Rowson \& Dott (1964) in their experiments with bull semen; the results indicated that $\mathrm{X}$-irradiation with $500 \mathrm{r}$ caused less damage if carried out at $-79^{\circ} \mathrm{C}$ than at $+4^{\circ} \mathrm{C}$. However, additional experiments (Rowson \& Dott, unpublished) failed to confirm this preliminary result and cast some doubt on the value of the low temperature method as a means of protecting spermatozoa effectively against ionizing radiation. In the present study the second method was used.

Rabbit semen was collected by means of an artificial vagina and diluted with $0.9 \% \mathrm{NaCl}$ so as to contain $100 \times 10^{6}$ spermatozoa $/ \mathrm{ml}$. The diluted semen was then divided into six samples and put into six glass tubes which were filled in pairs with nitrogen, air or oxygen for 10 to $12 \mathrm{~min}$. The oxygen tension was checked with a platinum electrode. The six tubes were sealed and one tube from each of the three pairs was exposed to $800 \mathrm{r}$ at $100 \mathrm{r} / \mathrm{min}$, the other served

* Postal address: Animal Research Station, 307 Huntingdon Road, Cambridge, England. 
as a control. After irradiation, $0.5 \mathrm{ml}\left(50 \times 10^{6}\right.$ spermatozoa) samples were inseminated into does which were then intravenously injected with 90 i.u. HGG to induce ovulation. The does were killed either 2 or 6 days after insemination and the eggs recovered and examined as described by Chang et al. (1957).

The results of inseminations are given in Table 1 . They agree closely with those previously reported by Chang et al. (1957), namely that the insemination of spermatozoa after X-irradiation in vitro with $800 \mathrm{r}$ in the presence of air did not affect the proportion of eggs fertilized, but the number of normal blastocysts produced was distinctly reduced. Furthermore, neither the proportion of eggs fertilized nor the proportion of normal blastocysts produced was altered by replacing the air with either oxygen or nitrogen. This might be taken as an

\section{TABLE 1}

RESULTS OF INSEMINATIONS WITH RABBIT SPERMATOZOA WHICH HAD BEEN IRRADIATED in vitro IN THE PRESENGE OF NITROGEN, AIR OR OXYGEN

\begin{tabular}{|c|c|c|c|c|c|c|c|c|c|c|c|c|c|c|c|c|}
\hline $\begin{array}{l}\text { Gas phase at } \\
\text { irradiation }\end{array}$ & \multicolumn{4}{|c|}{ Nitrogen } & \multicolumn{4}{|c|}{ Air } & \multicolumn{4}{|c|}{ Oxygen } & \multicolumn{4}{|c|}{$\begin{array}{c}\text { Total } \\
\text { (all gases) }\end{array}$} \\
\hline $\begin{array}{l}\text { Irradiation } \\
\text { dosage }(r)\end{array}$ & \multicolumn{2}{|c|}{0} & \multicolumn{2}{|c|}{800} & \multicolumn{2}{|c|}{0} & \multicolumn{2}{|c|}{800} & \multicolumn{2}{|c|}{0} & \multicolumn{2}{|c|}{800} & \multicolumn{2}{|c|}{0} & \multicolumn{2}{|c|}{800} \\
\hline $\begin{array}{l}\text { Time between } \\
\text { insemination } \\
\text { and examination } \\
(\text { days })\end{array}$ & 2 & 6 & 2 & 6 & 2 & 6 & 2 & 6 & 2 & 6 & 2 & 6 & 2 & 6 & 2 & 6 \\
\hline $\begin{array}{l}\text { No. of animals } \\
\text { inseminated }\end{array}$ & 5 & 6 & 6 & 5 & 6 & 5 & 6 & 7 & 6 & 5 & 6 & 5 & 17 & 16 & 18 & 17 \\
\hline $\begin{array}{l}\text { No. of corpora } \\
\text { lutea }\end{array}$ & 65 & 78 & 61 & 60 & 84 & 50 & 62 & 82 & 65 & 59 & 62 & 54 & 214 & 187 & 185 & 196 \\
\hline $\begin{array}{l}\text { No. of eggs } \\
\text { recovered }\end{array}$ & & 73 & & 45 & 69 & 43 & & 62 & 55 & 46 & 54 & 50 & 185 & 162 & 152 & 157 \\
\hline $\begin{array}{l}\% \text { of eggs that } \\
\text { had cleaved }\end{array}$ & 84 & 95 & 83 & 89 & 87 & 86 & 93 & 60 & 88 & 87 & 72 & 94 & 86 & 90 & 82 & 79 \\
\hline $\begin{array}{l}\% \text { of eggs which } \\
\text { developed into } \\
\text { normal } \\
\text { blastocysts }\end{array}$ & & 55 & & 15 & & 68 & & 24 & & 48 & & 17 & & 56 & & 19 \\
\hline
\end{tabular}

indication that the damage suffered by spermatozoa at irradiation results from a direct ionizing action of X-rays on DNA.

On three occasions the diluted semen was incubated at $37^{\circ} \mathrm{C}$ with nitro-blue tetrazolium (Borden Chemical Co.) and appropriate substrates to demonstrate the dehydrogenase activity against succinate, ethanol, lactate, $\alpha$-glycerophosphate and glutamate (Hess, Scarpelli \& Pearse, 1958a, b). After incubation the colour intensity of the reaction produced in the midpiece of the spermatozoa was estimated by examining the spermatozoa under an oil immersion objective $(\times 1000)$. No difference was noted between spermatozoa from the irradiated and control samples. These results are in accordance with the fact that even much higher doses of irradiation do not affect the metabolism of spermatozoa (cf. Mann, 1964). 
This work was supported by grants (RH-00309, GM-10529) from U.S.P.H.S. One of us (H.M.D.) wishes to acknowledge leave of absence from the Agricultural Research Council Unit of Reproductive Physiology and Biochemistry.

Sincere thanks are due to Miss Dorothy M. Hunt for assistance throughout this study.

\section{REFERENCES}

Amoroso, E. C. \& Parkes, A. S. (1947) Effects on embryonic development of X-irradiation of rabbit spermatozoa in vitro. Proc. $R$. Soc. B, 134, 57.

Chang, M. C., Hunt, D. M. \& Romanofr, E. B. (1957) Effects of radiocobalt irradiation of rabbit spermatozoa in vitro on fertilization and early development. Anat. Rec. 129, 211.

EDwards, R. G. (1957) The experimental induction of gynogenesis in the mouse. I. Irradiation of sperm by X-rays. Proc. R. Soc. B, 146, 469.

Hess, R., Scarpelli, D. G. \& Pearse, A. G. E. (1958a) Cytochemical localization of pyridine nucleotide-linked dehydrogenase. Nature, Lond. 181, 1531.

Hess, R., Scarpelli, D. G. \& Pearse, A. G. E. (1958b) Cytochemical localization of oxidative enzymes. II. Pyridine nucleotide-linked dehydrogenases. F. biophys. biochem. Cytol. 4, 753.

MANN, T. (1964) Biochemistry of semen and of the male reproductive tract. Methuen, London.

Rowson, L. E. A. \& DotT, H. M. (1964) Effect of insemination of liquid and frozen bovine semen after irradiation in vitro. Proc. Vth int. Congr. Anim. Reprod., Trento, 4, 552. 